\title{
Pre-1980 Eruptive History of Mount St. Helens, Washington
}

\begin{abstract}
$\mathrm{M}$
ount St. Helens, famous for its explosive 1980 eruption, has long been the most active volcano in the Pacific Northwest. U.S. Geological Survey (USGS) scientists have documented the volcano's 300,000year geologic history, including powerful explosions of ash, outpourings of lava, and huge landslides and volcanic mudflows. Understanding this history helps USGS scientists evaluate current activity at Mount St. Helens so that timely warnings of hazards can be issued to the public.
\end{abstract}

On May 18, 1980, Mount St. Helens, Washington, exploded in a spectacular and devastating eruption that brought the volcano to the attention of the world. Few people realized that Mount St. Helens had long been the most active volcano in the Cascade Range of the Pacific Northwest. It has a rich and complex 300,000-year history and has produced both violent explosive eruptions of volcanic ash and pumice and relatively quiet outpourings of lava. The volcano's edifice was mostly built by lava domes and flows from numerous eruptions. Using evidence in these lavas and other deposits, U.S. Geological Survey (USGS) scientists have documented dozens of major individual eruptions of the volcano.

An extensive apron of ash and fragmented volcanic rocks surrounds Mount St. Helens and mostly fills the valleys draining its slopes. This material was transported by pyroclastic flows (searingly hot flows of ash and volcanic gases), lahars (volcanic mudflows), and debris avalanches (landslides). Farther away from the volcano, pumice and ash that fell during explosive eruptions form layers that bury the landscape to depths of 10 feet or more.

The pre-1980 eruptive history of Mount St. Helens is strongly episodic. Volcanologists have recognized and named four episodes of volcanic activity, called "stages" Ape Canyon, Cougar, Swift Creek, and Spirit Lake - separated by dormant intervals. The youngest stage, Spirit Lake, is further subdivided into six eruptive periods. Because the preservation of deposits and other geologic

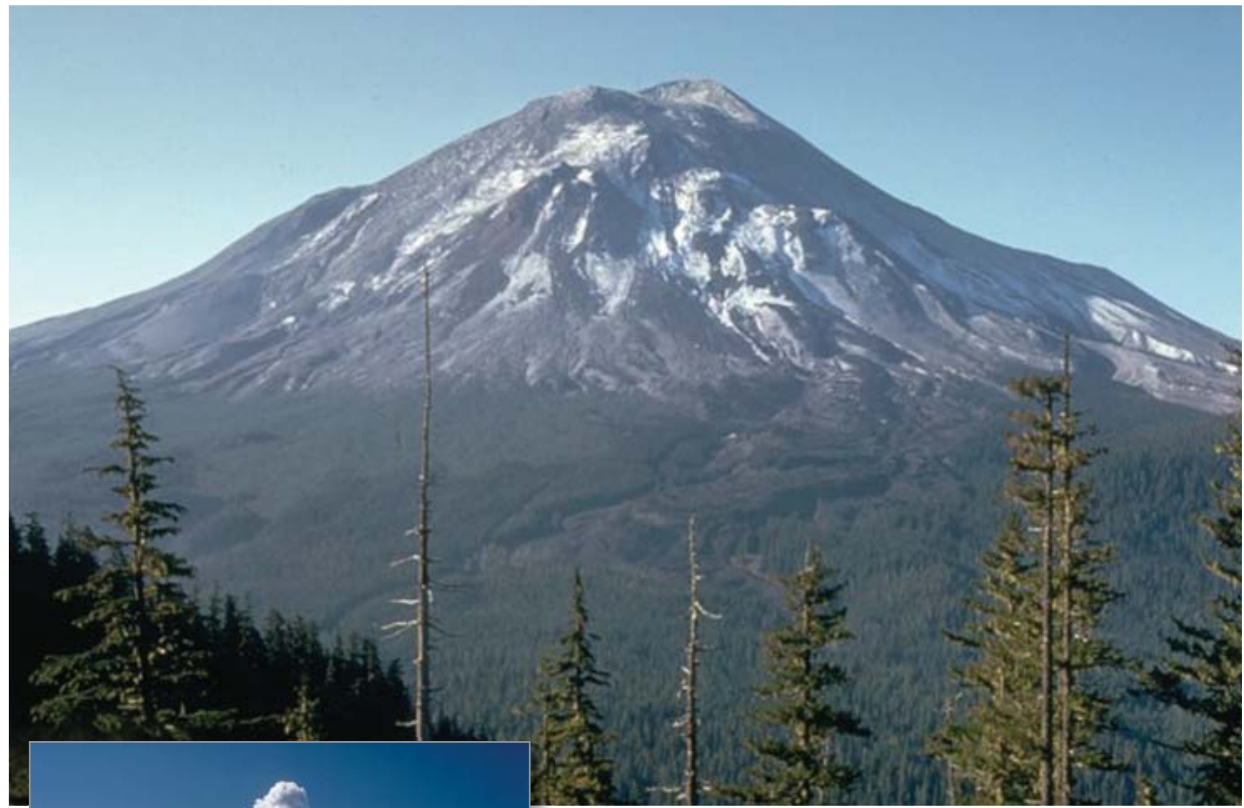

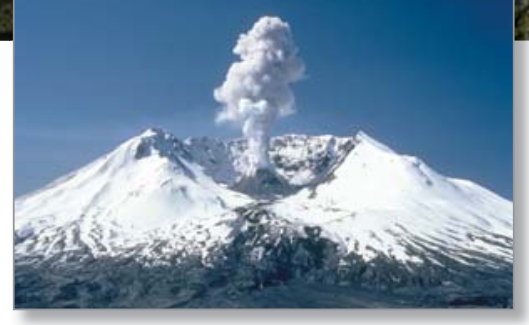

evidence is best for the youngest stages, the farther scientists look back in time the less detail they can infer for the history of volcanism at Mount St. Helens.

\section{Ape Canyon Stage (300 to 35 ka)}

The early history of Mount St. Helens is poorly known, and a long timespan is covered by the Ape Canyon Stage. During this stage, lava domes erupted west of the present edifice of the volcano in two distinct periods-one from 300 to 250 thousand years ago $(\mathrm{ka})$ and a second from 125 to $35 \mathrm{ka}$. A number of ash layers, called the " $\mathrm{C}$ " set, are clearly related to volcanism during the younger phase of the Ape Canyon Stage, and a few ashes found in central Washington older than the $\mathrm{C}$ set are also from Mount St. Helens. Although some Ape Canyon-age lava domes are exposed in the area of Goat Mountain and Butte Camp, the best record of early Mount St. Helens volcanism is preserved in the Cougar-age debris avalanche (see below) and in glacial deposits and lahars in the Lewis River Valley.
Mount St. Helens rises majestically above surrounding forests in this photo taken on May 17, 1980. In the devastating eruption the following day, 57 people were killed, most of the forest destroyed, and 1,300 feet of volcanic rock removed from the volcano's edifice, lowering its summit elevation to 8,364 feet (inset photo). During the volcano's 300,000-year history, dozens of eruptions have repeatedly changed its appearance. (USGS photos by Harry Glicken and Lyn Topinka.)

Many Ape Canyon-age rocks were altered hydrothermally (by volcanically heated ground water), indicating that an extensive hydrothermal system existed during the latter part of the stage. Volcanism during the Ape Canyon Stage produced a small cluster of lava domes with maximum elevations of about 4,000 feet.

\section{[Dormant Interval 35 to $23 \mathrm{ka}$}

\section{Cougar Stage (23 to $17 \mathrm{ka}$ )}

During the Cougar Stage, Mount St. Helens produced lava domes and flows, as well as explosive eruptions that ejected large volumes of ash and generated pyroclastic flows. A huge debris avalanche and subsequent lahars were also emplaced. This avalanche (Cougar debris avalanche) is composed primarily of Ape Canyon-age rocks and was the most devastating event of the stage. The debris avalanche originated in the area of Butte Camp and emplaced a deposit 600 to 900 feet thick on the south flank of the volcano. This 
avalanche, which was at least twice as large as the huge debris avalanche that triggered Mount St. Helens' 1980 eruption, dammed the Lewis River. Downcutting of the dam caused flooding downstream as far as the Columbia River and filled the lower Lewis River Valley with volcanic debris (ash and broken rock) at least 200 feet thick.

The Cougar debris avalanche was followed by a large explosive eruption producing pyroclastic flows that buried the avalanche deposits with a 300-foot-thick sheet of dacite pumice (the "2-pumice pf"). (Dacite is volcanic rock containing 63 to $68 \%$ silica $\left[\mathrm{SiO}_{2}\right]$.) Continued explosive activity deposited ash sets " $\mathrm{M}$ " and " $\mathrm{K}$ " and more pyroclastic flows (the "white pumice"). The Cougar Stage culminated with the eruption of the largest lava flow in the history of Mount St. Helens (Swift Creek flow). The vent for this andesite (53 to $63 \% \mathrm{SiO}_{2}$ ) lava flow, at an elevation of 6,000 feet on the south flank of Mount St. Helens, marks the summit of the volcano at that time.

\section{[Dormant Interval 17 to $13 \mathrm{ka}$ ]}

\section{Swift Creek Stage (13 to 11 ka)}

During the Swift Creek Stage, explosive eruptions produced two widespread ash layers, and three extensive fans of volcanic debris were emplaced from growing, unstable dacite lava domes. The Swift Creek fan, composed of pyroclastic flows and lahars, buried Cougar-age deposits on the south flank of Mount St. Helens. The Crescent fan consists of pyroclastic flows at least 600 feet thick on the west flank of the volcano that were derived from the Crescent lava dome. The Cedar Flats fan completely filled the ancestral valley of Pine Creek and spilled into the Lewis River at Cedar Flats. It was at least 300 feet thick in the Cedar Flats area. This fan is dominated by lahar deposits, but also contains pyroclastic material produced by collapses of lava domes.

All three fans are associated with the deposition of ash set "S" dated at 13 to 12.5 ka. The Swift Creek Stage culminated with deposition of ash set "J" at about 11.5 to 11 ka. At the end of Swift Creek time, Mount St. Helens consisted of a cluster of dacite domes with elevations as high as 7,000 feet.

\section{[Dormant Interval 11 to $3.9 \mathrm{ka}$ ]}

\section{Spirit Lake Stage (3.9 ka to present)}

The bulk of the pre-1980 edifice of Mount St. Helens was constructed by eruptions during the Spirit Lake Stage. Excellent preservation of deposits, as well as numerous ages from radiocarbon and tree-ring dating, provide considerable detail for this stage. Volcanism was intermittent, with lulls on the order of a few to about 600 years. As in earlier stages, Spirit Lake volcanism erupted mostly dacite, but significant amounts of basalt (less than $53 \% \mathrm{SiO}_{2}$ ) and andesite were also erupt-

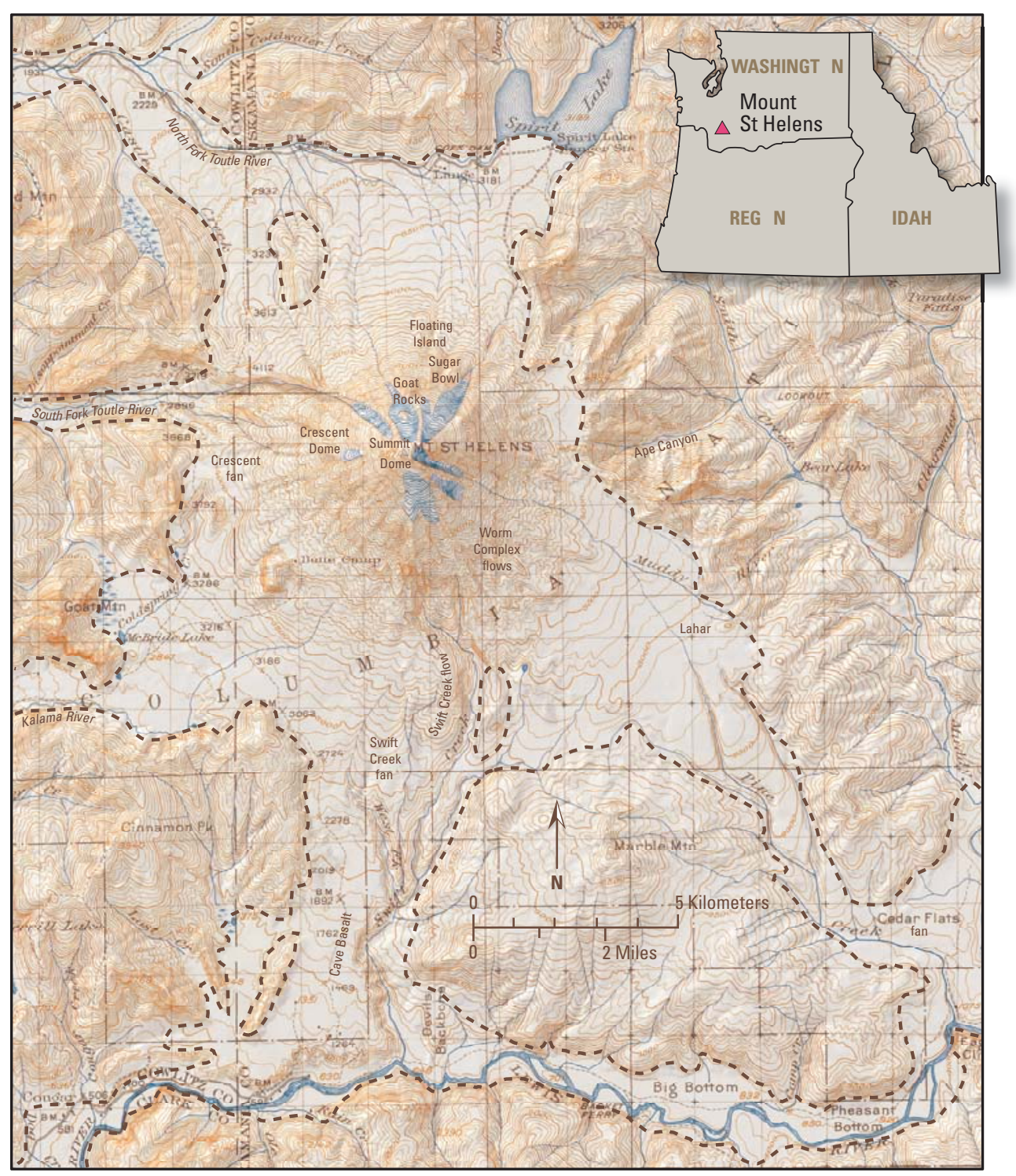

This map, originally produced by the U.S. Geological Survey in 1919, shows the pre-1980 topography of Mount St. Helens. The gentle slopes on the flanks of the volcano are fans of volcanic debris and consist of ash, pumice, and volcanic rock fragments. Dashed lines show the extent of these fans.

ed. The Spirit Lake Stage is subdivided into six eruptive periods - the Smith Creek, Pine Creek, Castle Creek, Sugar Bowl, Kalama, and Goat Rocks Eruptive Periods.

\section{Smith Creek Eruptive Period (3.9 to 3.3}

ka)—During this period, Mount St. Helens erupted mostly ash. Two periods of activity, about 3.90 to $3.85 \mathrm{ka}$ and 3.5 to $3.3 \mathrm{ka}$, deposited set "Y" ashes. The second period was initiated with an eruption that produced "Yn" ash. This eruption, possibly the most voluminous in Mount St. Helens' history, was about four times larger than the 1980 eruption. During late Smith Creek time, huge lahars swept down the Toutle River, and some probably reached the Columbia River. The primarily ash-producing eruptions of Mount St. Helens during Smith Creek time did not significantly change the volcano's shape.

Pine Creek Eruptive Period (2.9 to $\mathbf{2 . 5 5}$ ka)_During the Pine Creek Eruptive Period,
Mount St. Helens erupted ash and produced pyroclastic flows and dacite domes, and two small debris avalanches occurred on its north flank. Repeated collapse of hot, growing lava domes produced an extensive and broad fan of volcanic debris as much as 600 feet thick on the south flank of the volcano. Similar deposits on the north flank can still be found as far downstream as the town of Toutle. Pine Creek-age dacite domes exposed in the walls of the crater left by the 1980 eruption show that at the end of Pine Creek time, the volcano was a cluster of lava domes with a maximum elevation of about 7,000 feet.

\section{Castle Creek Eruptive Period (2.55 to} 1.895 ka)—The Castle Creek Eruptive Period produced many lava flows and domes, pyroclastic flows, and ash. Andesite lava flows and ash erupted from the summit were emplaced on all flanks of Mount St. Helens between 2.55 and about $2.50 \mathrm{ka}$. A lull of about 300 


\section{CHRONOLOGY OF ERUPTIVE ACTIVITY AT MOUNT ST. HELENS}
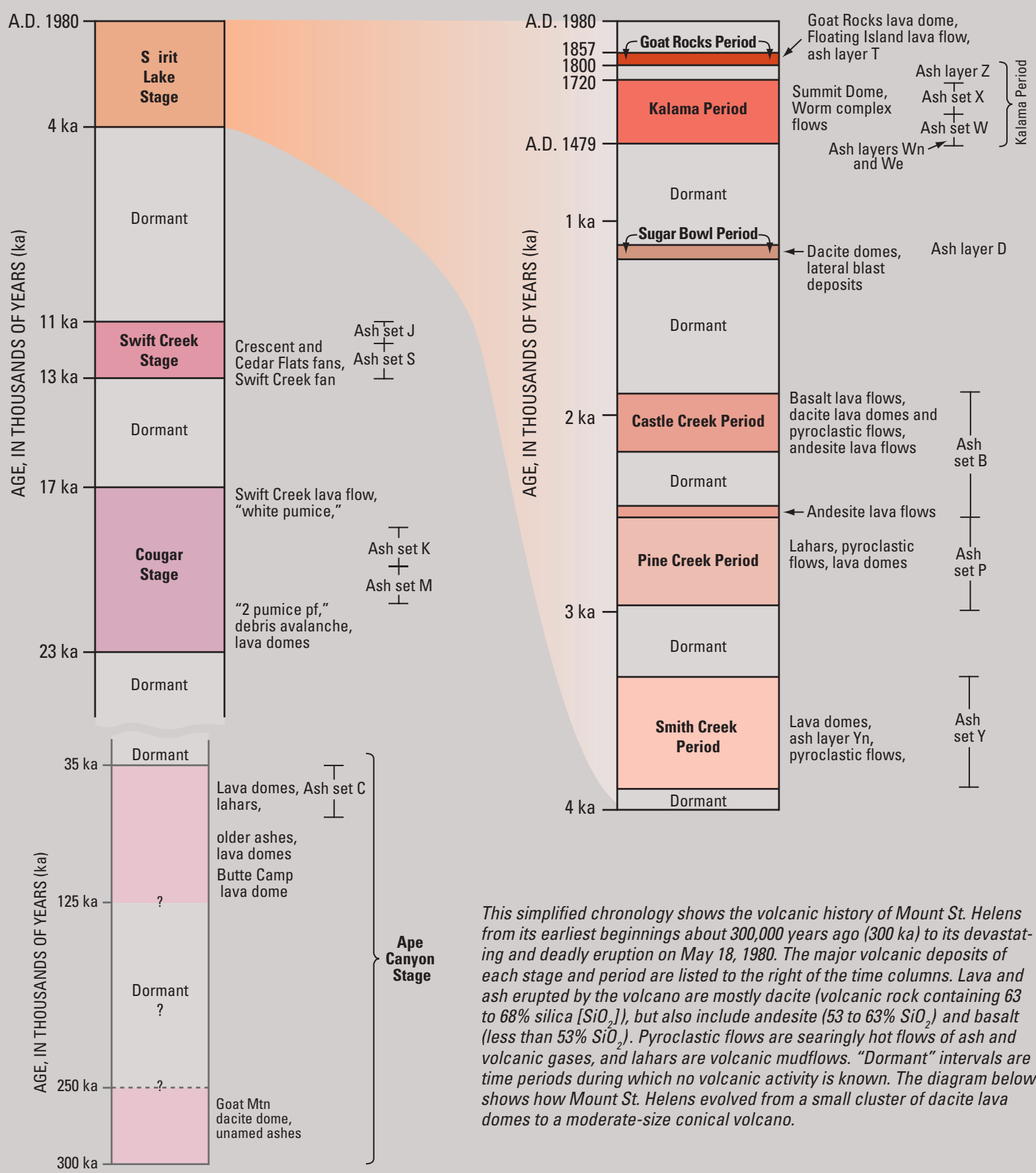

This simplified chronology shows the volcanic history of Mount St. Helens from its earliest beginnings about 300,000 years ago (300 ka) to its devastating and deadly eruption on May 18, 1980. The major volcanic deposits of each stage and period are listed to the right of the time columns. Lava and ash erupted by the volcano are mostly dacite (volcanic rock containing 63 to $68 \%$ silica [ $\left.\mathrm{SiO}_{2}\right]$ ), but also include andesite (53 to $63 \% \mathrm{SiO}_{2}$ ) and basalt (less than $53 \% \mathrm{SiO}_{2}$ ). Pyroclastic flows are searingly hot flows of ash and volcanic gases, and lahars are volcanic mudflows. "Dormant" intervals are time periods during which no volcanic activity is known. The diagram below shows how Mount St. Helens evolved from a small cluster of dacite lava domes to a moderate-size conical volcano.

The Profile of Mount St. Helens Through Time

ELEVATION

IN FEET

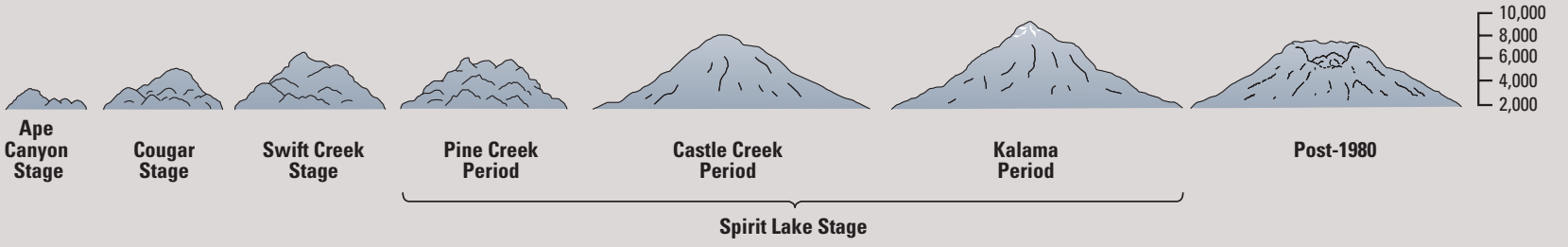




\section{THE HISTORY OF MOUNT ST. HELENS IS WRITTEN IN LAYERS OF ASH}

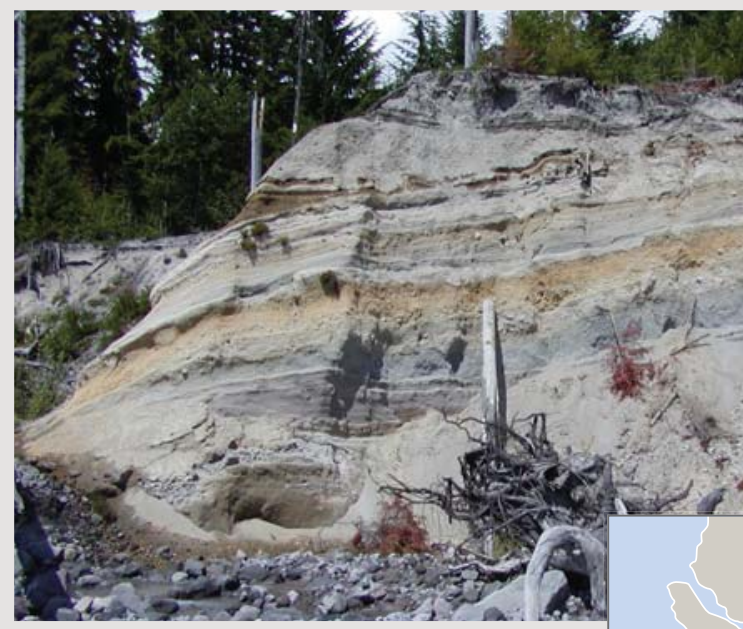

By examining layers of volcanic ash (tiny jagged particles of volcanic rock and glass) and pumice deposited by successive explosive eruptions, U.S. Geological Survey scientists have deciphered the eruptive history of Mount St. Helens. Groups or "sets" of ash layers of similar age are designated with letters and signify explosive episodes in the volcano's history. Ages of ash layers less than 50,000 years old are determined by radiocarbon dating of wood or charcoal trapped in the ash. The 20-foot-high cliff at "Stratigraphy Viewpoint" along the Muddy River (photo above) exposes a series of deposits from the past 13,000 years of Mount St. Helens' history. The prominent yellow-brown layer in the middle is part of ash set " $Y$ " from the Smith Creek Eruptive Period. The cliff is capped by deposits several feet thick from the volcano's devastating 1980 eruption. Major explosive eruptions not only leave deposits near the volcano but also inject fine ash (see inset photo) high into the atmosphere where wind can carry it great distances. The map shows the known distribution of recognizable ash layers from three fairly typical explosive eruptions of Mount St. Helens in the past few thousand years. The eruption that produced the " $Y n$ " ash was about four times as large as that of 1980 and was probably the largest explosive eruption in the volcano's history.

years followed, and volcanism resumed at about 2.2 ka with eruption of andesite lava flows on the volcano's north flank. Several thick dacite lava flows and domes, pyroclastic flows and ash, and lahars were produced at $2.0 \mathrm{ka}$. Castle Creek activity culminated with eruption of three groups of fluid basalt lava flows that poured down all flanks of the volcano as far as 8 miles. The Cave Basalt, erupted at $1.895 \mathrm{ka}$, was the most recent of these. Castle Creek lavas transformed the Pine Creek-age cluster of domes into a classic cone-shaped composite volcano, with a summit elevation of about 8,500 feet.

\section{Sugar Bowl Eruptive Period (1.2 to 1.15} ka [A.D. 850 to 900, corrected radiocarbon dates])—During the Sugar Bowl Eruptive Period, three lava domes were built on the flanks of Mount St. Helens. Explosive eruptions associated with growth of the Sugar Bowl Dome produced two "lateral blasts" that affected an area about one-tenth as large as that of the lateral blast in the 1980 eruption. Ash layer "D" and lahars were also emplaced. The Sugar Bowl period was short lived, produced a small volume of volcanic materials, and did not significantly change the appearance of the volcano.

Kalama Eruptive Period (A.D. 1479 to

1720)_Activity during this period produced large-volume dacite ashes, pyroclastic flows, domes, lahars, and andesite lava flows. Mount St. Helens added about 1,000 feet of elevation and attained its pre- 1980 form during the Kalama Period. The Kalama Eruptive Period is subdivided into three series of events - the early, middle, and late Kalama phases.

The early Kalama phase began in 1479 with a large pyroclastic eruption that deposited dacite ash layer "Wn." In 1482, a smaller eruption produced ash layer "We." Over the next 10 to 20 years, a number of lava domes grew in the volcano's crater and were disrupted by explosive eruptions. Lahars and pyroclastic flows associated with early Kalama eruptions are abundant on the volcano's west and south flanks.

The middle Kalama phase began about 1510 with eruption of andesite as pyroclastic flows (which generated hot lahars), a few lava flows, and ash set "X." The middle phase peaked about 1535 with eruption of the many thick andesite lava flows prominent on all flanks of Mount St. Helens, including the Worm Complex flows, and ended by 1570 .

The most significant event of the late Kalama phase was growth of a large dacite dome at the summit (Summit Dome). The Summit Dome took nearly 100 years to grow (1620 to 1720) and gave Mount St. Helens its pre- 1980 form. During growth, it shed material as pyroclastic flows and lahars on all flanks of the volcano. Mount St. Helens acquired its pre1980 cover of glaciers as a result of growth of the Summit Dome.

Goat Rocks Eruptive Period (A.D. 1800 1857)-The Goat Rocks Period was short and relatively small. An explosive eruption in 1800 produced ash layer "T" and was followed in 1801 by an andesite lava flow, called the "Floating Island," on Mount St. Helens' north flank. Eruptions observed intermittently from 1831 to 1857 produced ash and the Goat Rocks Dome, whose growth also resulted in a small fan of volcanic debris and lahars.

The last significant eruption of Mount St. Helens before 1980 is generally considered to have occurred in 1857. Minor explosions reported in 1898, 1903, and 1921 were probably steam-driven and not magmatic (molten rock) eruptions. Eruptions of the Goat Rocks Period did not significantly change the appearance of Mount St. Helens, but they added the final pieces to the edifice and set the stage for the 1980 eruption.

Recent work by scientists with the USGS in cooperation with the U.S. Forest Service is shedding new light on the 300,000-year history of Mount St. Helens Volcano. The work of these USGS scientists is only part of the USGS Volcano Hazards Program's ongoing efforts to protect people's lives and property in all of the volcanic regions of the United States, including the Pacific Northwest, eastern California, Wyoming, Alaska, and Hawaii.

Michael A. Clynne, David W. Ramsey, and Edward W. Wolfe

Edited by James W. Hendley II and Peter H. Stauffer Graphic design by Susan Mayfield and Sara Boore Banner design by Bobbie Myers

COOPERATING ORGANIZATIONS U.S. Forest Service

For more information contact:
U.S. Geological Survey
David A. Johnston Cascades Volcano Observatory
1300 SE Cardinal Court, BIdg. 10, Suite 100
Vancouver, WA 98683-9589
Tel: (360) 993-8900, Fax: (360) 993-8980
e-mail: cvo@usgs.gov
http://volcanoes.usgs.gov/
What are Volcano Hazards? (USGS Fact Sheet
002-97) and other USGS volcano Fact Sheets
http://volcanoes.usgs.gov/Products/sproducts.html
This Fact Sheet and any updates to it are available
online at
http://pubs.usgs.gov/fs/2005/3045

